\title{
Journey from academics to employment: labor market insertion of the Fitness and Motor Performance Master Physical Education Faculty of Timisoara West University Alumni 2011-2016- a pilot study
}

\author{
Adrian NAGEL ${ }^{1}$, Silvia Nicoleta MIRICĂ ${ }^{2}$, Martin DOMOKOS 3 , Cerasela DOMOKOS ${ }^{4}$, \\ Eugen BOTA ${ }^{5}$, Cristian NEGREA ${ }^{6}$
}

\begin{abstract}
Introduction: The great changes that occurred in the domain of sports and physical education requested the formation of a high qualified human resource. The concept of sport science greatly supported and promoted within European academic area was adopted also by Physical Education and Sport Faculty of The Timisoara West University (PESF-TWU) that has aligned its educational offer by developing the Master degree program in the field of Fitness and Motric Performance (FMPM). Thus, the framework for preparing a highly qualified human resource, capable to adjust to the changes of the labor market was established.

Aim: The aim of this pilot study was to analyze the dynamics of the professional insertion journey of FMPF Alumni. We evaluated the following category of parameters: alumni demographic indices, education level and parameters that characterize the job insertion.

Results: The data analysis showed a significant increase of the alumni during the last 5 years with a particular dynamics of age distribution during the study period: $80 \%$ of the participants were included in the 28-31 years of age category. The evaluation of dynamics during the years revealed that extreme age categories: 24-27 years and > 31 years presented a constant increase during the years comparing to the most representative age category. In terms of education, over $50 \%$ of the Alumni followed complementary courses and specializations in order to increase their expertise with an interesting gender distribution in favor of male group (male: $74 \%$ vs. female: $26 \%$, $<<0.0001$ ). Referring to the parameters that characterize job insertion data showed an increased speed in terms of first job employment: $82 \%$ of the Alumni were employed within a 6 month interval after graduation and only 3.8\% of the Alumni are jobless even after 3 years.

Conclusion: The results of this pilot study indicate that FMPM Alumni are well trained and able to adapt to the specific labor market needs in the field of sports and physical activity and education, suggesting that PESF-TWU through its education programs respects the high standards of performance promoted by the TWU.
\end{abstract}

Key words: professional insertion, master education programs, Alumni,

\section{Rezumat}

Introducere: Modificările importante care au apărut în domeniul sportului și al educației fizice au necesitat formarea unei resurse umane înalt calificate. Conceptul de știință a sportului este susținut și promovat de mediul academic și a fost adoptat și de către Facultatea de Educație Fizică și Sport din cadrul Universității de Vest Timișoara (FEFS-UVT) care și-a aliniat oferta educațională prin implementarea și dezvoltarea unui program de studii masterale în domeniul: Fitness și Performanță Motrică (MFPM). Astfel, au fost create premisele pentru a forma o resursă umană înalt calificată, capabilă să se adapteze la cerințele în continuă schimbare ale pieței muncii.

\footnotetext{
${ }^{1}$ Associate Professor PhD, West University of Timisoara, Sport and Physical Education Faculty, Romania, adrian.nagel@e-uvt.ro

${ }^{2} \mathrm{MD}, \mathrm{PhD}$, West University of Timisoara, Sport and Physical Education Faculty, Romania

${ }^{3}$ Associate Professor PhD, West University of Timisoara, Sport and Physical Education Faculty, Romania

${ }^{4}$ PhD candidate, West University of Timisoara, Sport and Physical Education Faculty, Romania

${ }^{5}$ Associate Professor PhD, West University of Timisoara, Sport and Physical Education Faculty, Romania

${ }^{6}$ Lecturer PhD, West University of Timisoara, Sport and Physical Education Faculty, Romania
}

Volume 10 Issue $19 \diamond 2017$ 
Scop: Scopul acestui studiu pilot a constat în analiza dinamicii tranziției inserției profesionale a absolvenților MFPM prin evaluarea următoarelor categorii de parametri: indici demografici, nivel educațional, și parametri ce caracterizează inserția profesională.

Rezultate: Analiza datelor arată o creștere semnificativă a numărului de absolvenți în ultimii 5 ani care prezintă o dinamică particulară în ceea ce privește distribuția pe categoriile de vârstă ale absolvenților: 80\% dintre absolvenți corespund categoriei 28-31 de ani. Evoluția dinamicii categoriilor de vârstă pe perioada studiată arată că în cazul categoriilor extreme de vârstă 24-27 respectiv > 31 de ani s-a observat o creștere constantă a numărului de absolvenți comparativ cu categoria de vârsta cea mai reprezentativă. În ceea ce privește educația, peste $50 \%$ dintre absolvenți au urmat cursuri și specializări complementare pentru a-și crește aria de expertiză. S-a observat o distribuție particulară pe sexe a acestui parametru, lotul masculin studiat prezentând un interes semnificativ mai crescut față de lotul feminin (74\% vs. 26\%, p< 0.001). În ceea ce privește parametrii care caracterizează inserția profesională, datele arată o viteză crescută de inserare profesională a absolvenților (82\%) în primele 6 luni după absolvire și un procent foarte redus al celor care nu au nici un loc de muncă la un interval de 3 ani după absolvire.

Concluzie: Rezultatele acestui studiu pilot arată că absolvenții MFPM sunt foarte bine instruiți și sunt capabili să se adapteze la nevoile specifice ale pieței muncii din domeniul sportiv și educațional, sugerând că FEFS-UVT, prin programele sale educaționale respectă standardele crescute de performanță promovate de UVT.

Cuvinte cheie: inserție profesională, programe educaționale masterale, absolvenți studii masterale. 


\section{Introduction}

"The skills and qualifications gained in university should help us build our lives and secure our societies' prosperity, competitiveness and progress"

- Tibor Navracsics European Commissioner for Education, Culture, Youth and Sport [1].

Great changes occurred in the last century in the sports domain activities. Thus, the development of great institutions that promote high performance, the creation of an entire high technology industry in the field and promotion the physical education in large masses requested the formation of a high qualified human resource.

The concept of sport science has a great support within academic area and addresses to the specialists involved in both developing physical education, physical activities and fitness programs but also for those who are involved in more specific fields like post-traumatic recovery and recuperation of persons with special needs.

The framework for this objective has been created by the universities that implemented higher educational programs in the field of physical activity and sports. Therefore, according to this socioeconomic and educational context, Physical Education and Sport Faculty of The Timisoara West University (PESF-TWU) has aliened its educational offer by implementing and developing the Master degree program in the field of Fitness and motor performance. The goal of this educational program is to generate a high qualified human resource in the field of fitness that can easily adapt to the necessities of the specific labor market both at national and international level.

Recent studies show that both in Europe and Romania the unemployment rate among the youth are increased, especially in this region [1, 2, 3, 4]. Data could be influenced by the determinant factors that characterize the transition of the young alumni from the academic statute to work and also by the economic and financial aspects of the specific domains accessed by the job appliers. Thus, the mobility of labor market, the know-how export and income related issues [5] together with the relationship between the gender distribution, education level, and the speed of the first job employment, play important key roles in determination of the alumni's actual economical, social status and quality of life $[4,6,7]$.

Therefore, considering level of employment as a performance indicator of the higher educational programs, evaluation of the alumni professional dynamics represents one of the most important objectives of the educational media such as universities and higher education institutions. Thus, following this modern approach PESF-TWU can be considered a player on the table in the European context.

To objectively describe the actual reality considering the insertion of the PESF-TWU master alumni on labor market, this study links the higher education and labor market opportunities in the field of sports industry by retrospectively analyzing the data for a 5 year period.

\section{Methodology}

The study represents a retrospective analysis of a 5 years period concerning the dynamics of the professional insertion journey of the Master of Fitness and Motor Performance Alumni from PESFTWU. The analyzed data were obtained by applying a satisfaction questionnaire designed by the PESFTWU team. In order to obtain accurate data there were established inclusion and exclusion criteria for the analyzed group:

\section{Inclusion criteria:}

i) all participants are Alumni of the Master Education Program: Fitness and Motor Performance along 2011-2016 period;

ii) the contacted Alumni should be compliant and respond to all questionnaire subjects.

\section{Exclusion Criteria:}

i) the lack of compliance by giving incomplete answers;

ii) impossibility to contact de Alumni by using the existing contact information.

For this research were analyzed several indicators as follows:

- alumni demographic indices: age and gender distribution of the alumni, first job employment distribution during analyzed period;

- education level: education level and motivation for choosing the field of education;

- parameters that characterize the job insertion: time interval between graduation and 
employment, correlation between jobs and the graduated education field and the degree of satisfaction concerning their actual job.

\section{Statistical analysis}

Data were compared and analyzed by statistic analyzing software GraphPad Prism 5.0 and Microsoft Excel. Group comparisons were performed by Student t- test and one-way analysis of variance (ANOVA) and Bonferroni's post-hoc multiple comparison test. $p<0.05$ was considered significant.

\section{Results}

From all 62 alumni, that were contacted, 52 presented full compliance to the questionnaire, representing over $80 \%$ of the questioned group.

\section{Alumni demographic indices}

\section{a) Age and gender distribution of the alumni}

From the total questioned alumni that presented $100 \%$ compliance for the study $44 \%$ were represented by females and $56 \%$ by males.

The most representative age category, represented by $80 \%$ of the participants was between $28-31$ years of age (fig 1). The most interesting dynamics is represented by the extreme age categories: $24-27$ and $>31$ years of age that showed a significant increase in number of participants over the last 3 years of the study period comparing with the initial years. Opposite, the most represented category showed an abrupt decrease in the last 2 years on analyzing. This particular alumni age distribution dynamics suggests an increased interest in finalizing the superior education for both young and mature graduates.

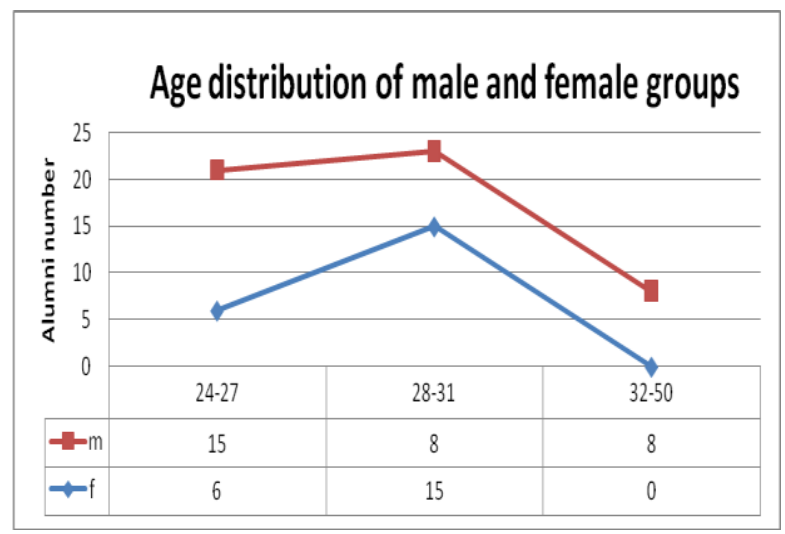

Figure 1. Age-gender distribution
The global analysis shows that the great majority of the alumni are in 24-31 years age category. The gender distribution revealed that $100 \%$ of females and $74 \%$ of males are included in this category. The interesting distribution is represented into 28-31 years of age category that included $71 \%$ of the female group.

Also, we observed significant differences considering the evolution of the alumni number during the study period. Thus, the class of 2014 showed the highest rate of alumni number augmentation (55\%) comparing to the first 2 graduation years (class of 2014 vs. class of 2012, $2013-\mathrm{p}<0.05$ ). During the last 2 years of study period there was no significant augmentation of the alumni number comparing with the class of 2014 as shown in fig 2.

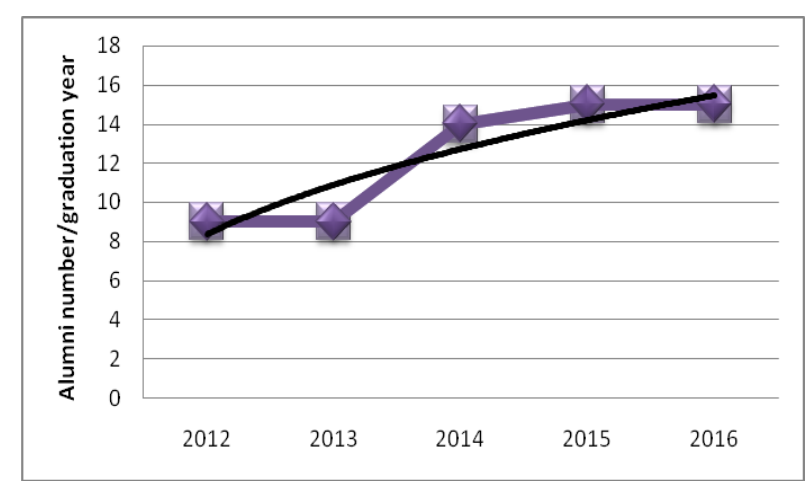

Figure 2. Alumni graduation dynamics over the studied period

\section{b) Education}

According to the studies, the education level represents one of the the most important predictive factor for the individual's insertion on the labor market $[8,9,10,11,12]$. A higher education level ensures a lower unemployment risk and also ensures a higher quality of life by an increased potential income. According to Eurostat data, the share of the young people with low education slightly exceeds $50 \%$ in Romania which places our country near other countries like Netherlands, Denmark, Germany, Bulgaria, Austria, and Italy (8). Into the field of Physical Education, our data show that $51 \%$ of the FMPM Alumni increased their education by attending other courses and related specializations. Considering the gender distribution, from those Alumni that enlarged their area of 
expertise, the male group showed a significantly higher interest than female (male:74\% vs. female: $26 \%), \mathrm{p}<0.001$.

An interesting result is revealed by the image in fig 3. The analysis of the motivation to attend the FMPM program showed that about $60 \%$ of the subjects wanted an increase of the education level, $51 \%$ of the Alumni attended the program in order to promote or to apply for a higher position and $21 \%$ attended the program out of curiosity. Also, there analysis revealed gender differences concerning the motivation in attending FMPM.

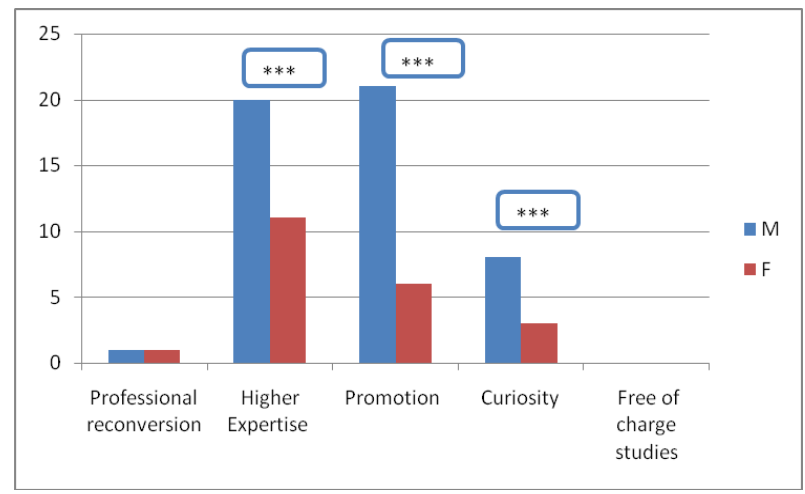

Figure 3. Motivation to attend FMPM program

\section{c) First job employment distribution during analyzed period}

The first job employment gender distribution analysis reveals that over $80 \%$ of the Alumni got their job in a 6 month interval post-graduation. Analyzing gender distribution there is a significant difference between male and female groups. For the first 6 month post-graduation interval corresponding to a high academic-work transition speed- the employment rates were significantly higher in the male group versus female group (male group: $84 \%$ vs. female group: $77 \%, \mathrm{p}<0.05$ ). This trend was not respected as well for the rest of the post-graduation time intervals. After 6 month postgraduation, it was revealed a decreased employment rates together with the decrease of transition speed with no significant differences among the gender studied groups (p-ns) (fig 4).

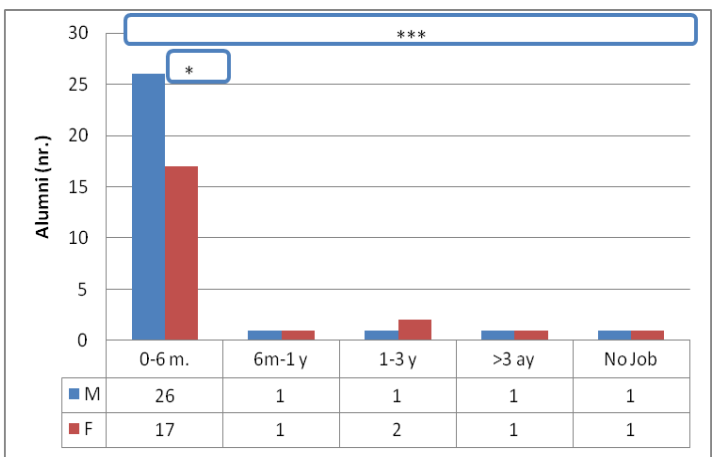

Figure 4. Alumni employment rates according to the post-graduation time interval

Gender distribution concerning professional insertion reveals that both males and females groups got their first post graduation job in 6 month interval. Data comparison showed a significant difference in favor of male group (male: $84 \%$ vs. female $77 \%, \mathrm{p}<0.05$ ). For the rest of the analyzed time intervals there were not noticed significant differences between groups (p-ns). The multiple comparison analysis reveals a very significant difference in terms of employment rates for both groups comparing with the first 6 month postgraduation interval $(\mathrm{p}<0.001)$

The main domains preferred by the Alumni in terms of professional insertion are presented in fig 5 .

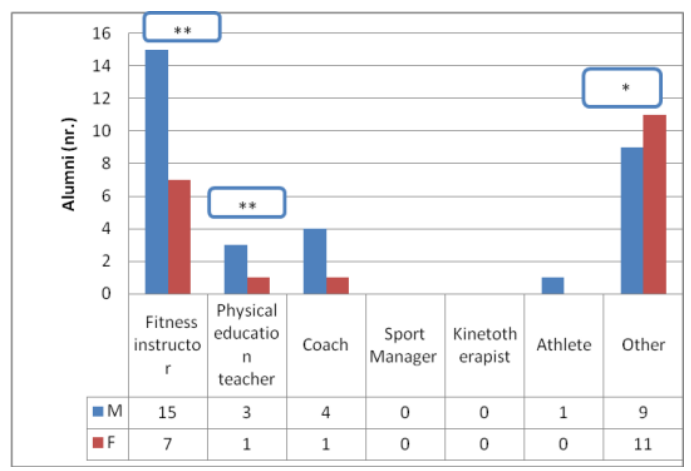

Figure 5. Main working areas attended by the Alumni

The data analysis revealed a particular trend concerning the female group concerning the insertion according to their area of expertise. Thus, the females Alumni preferred to work in other domains in proportion of $55 \%$ comparative to males Alumni who considered working in other domains than their area of expertise in only $28 \%$ of the cases $(\mathrm{p}<0.01)$. On the other hand the fitness industry 
absorbed $47 \%$ of male Alumni versus $37 \%$ of female Alumni $(\mathrm{p}<0.01)$. The same trend can be noticed for physical education domain where work almost twice male than female Alumni (male: $9 \%$ vs. females: $5 \%$, $\mathrm{p}<0.01$ ).

The most applied domain is represented by the fitness industry with $42 \%$ of the Alumni and the opposite pole is represented by the Education field with only $7 \%(\mathrm{p}<0.001)$.

Degree of satisfaction at actual job and annual distribution are presented below (Table 1, fig 6). The data showed that the level of satisfaction at their actual job is over average for all the Alumni.

Table I. Annual distribution dynamics concerning degree of satisfaction

\begin{tabular}{|c|c|c|c|c|c|c|c|c|c|c|}
\hline Year & \multicolumn{2}{|c|}{2012} & \multicolumn{2}{|c|}{2013} & \multicolumn{2}{|c|}{2014} & \multicolumn{2}{|c|}{2015} & \multicolumn{2}{|c|}{2016} \\
\hline Gender & $\mathrm{M}$ & $\mathrm{F}$ & $\mathrm{M}$ & $\mathrm{F}$ & $\mathrm{M}$ & $\mathrm{F}$ & $\bar{M}$ & $\mathrm{~F}$ & $\mathrm{M}$ & $\mathrm{F}$ \\
\hline Very high & 2 & 3 & 2 & 1 & 4 & 1 & 1 & 1 & 4 & 0 \\
\hline High & 0 & 1 & 1 & 4 & 4 & 1 & 2 & 3 & 5 & 1 \\
\hline Medium & 0 & 2 & 0 & 0 & 0 & 1 & 1 & 1 & 1 & 1 \\
\hline Very low & 0 & 0 & 0 & 0 & 0 & 0 & 0 & 0 & 0 & 0 \\
\hline Unsatisfactory & 0 & 0 & 0 & 0 & 0 & 0 & 0 & 0 & 0 & 0 \\
\hline
\end{tabular}

The gender distribution respected also the general result, but there are a few diferences among groups in terms of level of satisfaction. Thus, majority of the male group indicated a very high degree satisfaction comparing to female group (males: $48 \%$ vs. females:25\%, p<0.01). On the other hand the number of females that indicated a medium degre of satisfaction comparing to males was significantly higher (males: 7\% vs females: $25 \%$, p<0.01).

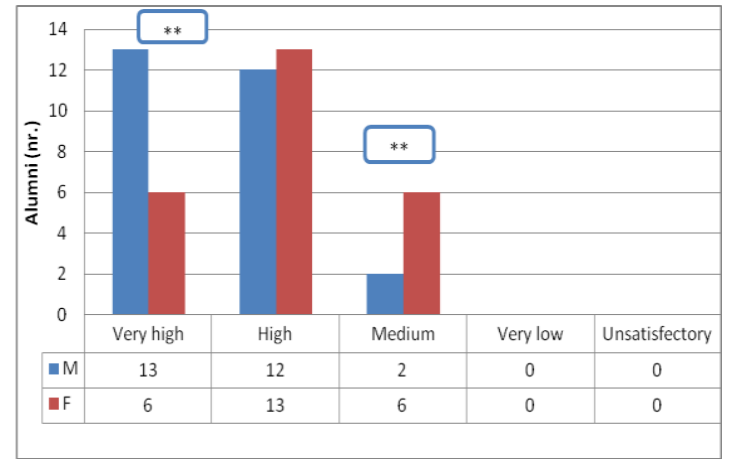

Figure 6. Satisfaction degree at actual job - gender distribution

\section{Discussion}

There are only a few studies regarding the Alumni integration on labor market that have a direct and punctual approach, such as Sport science and Physical education.

Thus, our study could be considered a pilot study representing the first step in a greater project of surveying the Alumni careers over the next decade.

Comparing with the Eurostat Sport statistics 2016 edition [14] our results revealed a great gender distribution similarity considering the employment rate in the field of sport. Thus, both in European statistics and in our study the male group represented over $50 \%$ of the subjects.

Considering the age distribution, comparing to the European stasistics we found that there are differences regarding the human resource age. These differences are probably related to the fact that our study represents only the begining of a long term prospective study of analysing our Alumni professional journey that started in 2017. Therefore, the data will be completed in the following years. However, the Eurostat 2016 shows that, at European level, the great majority of the employees involved in the field of sport (over $60 \%$ ) are in the group of 35-64 years of age, comparing to our statistics that showed a younger human resource for the Alumni. The great majority in our study is represented by the 24-31 years of age category, 84\%, comparing to the European statistics that reveled a decreased rate of only $36 \%$ for the employees below 30 years of age. An issue of a great importance is that in European statistics in 2015 Romania wasn't even listed in the graph of persons with tertiary education attainment in sport and in total employment [14]. So, our study can be considered a great oportunity for our University to became more visible in both Romania and Europe, considering that all of our Alumni have a master degree in their portfolio. Another interesting issue is that in 2013, Romania was placed on the third place in European Union after Italy and France considering the number of graduates in sport disciplines [15]. At that moment, at Timisoara West University, the second generation of the Alumni graduated the MPFM program. From that moment the interest for this master program grew constantly during the following years. 
In terms of unemployment rate of youth in all activity fields, Romania is considered to be medium [3]. Considering the employment rates in sport, the Eurostat shows that in most EU Member States, they rose between 2011 and 2015 [16]. In case of Romania it can be seen a fluctuation of the employment in sport in 2011-2015, the greatest range being registered in 2013. Still the average annual growth rate was only of $1.9 \%$ ranking us in the 23rd place in Europe. Considering that we were in the top 3 in Europe in termes of number of graduations we could expect a better share of total employment in sports jobs. Though, the analysis revealed that in, Romaina, the employment in the field is still at lowest range in Europe, only $0.1 \%$ and remained constant during 2011-2015.

According to our results, we found that the employment rates of our Alumni were significantly higher that the country's avarage. Still, the share of women and men employed in sport reported by the Eurostat in 2015, reveled a great disproportion between genders in Romania [17]. Our study also confirmed this trend, a higher number of males being integrated in the labor market specially in the first 6 month postgraduation. However, not all the Alumni attended the jobs in the field of sport.

Comparing our results with the study conducted in 2009 at the University of West Bohemia in Pilsen the characteristics of Alumni who studied the Physical education and sport revealed that demographics indices are similar considering the gender distribution [18].

The interesting difference is represented by the motivation in attending the specific educational programs. Over $50 \%$ of the Romanian Alumni wanted an increase of their education level and to promote or to apply for a higher position and only $20 \%$ were motivated by the curiosity comparing to Bohemian Alumni that were motivated to attened the sport education filed based on the fact that they simply "like to do sport" [18]. Also, the motivation of attendning a specific educational program was reveled by the domain when the Alumni choose their career to be. Thus, one third of the West Bohemian University Alumni prefered their main job to be in schools (at different levels) in contrast with the Timisoara West University Alumni who prefered, in their great majority, to work in the fitness industry.

Another analzed parameter was the additional education attended by the Alumni. There were found great similarities between the Alumni groups. Thus, over 51\% Alumni from both Universities choose to increase their level after graduation.

The satisfaction degree was better analyzed by the czech study, considering the categories of analyzed data. But, we can say that even we do not have the detailed data as depicted by the West Bohemia University study, yet, we obtained comparable results in terms of global approach.

\section{Conclusion}

The results of this pilot study indicate that FMPM Alumni are well trained and able to adapt to the specific labor market needs and opportunities in the field of sports and physical activity and also in education field or other related domains, suggesting that PESF-TWU through its higher educational programs respects the high standards of performance promoted by the TWU. This pilot study opens a new field of research that can lead to development of new strategies in order to meet the need of increased performance for both Alumni and faculty.

\section{References}

1. Bartlett W., Uvalić M., Durazzi N., Monastiriotis V., Sene T. (2016). From University to Employment: Higher Education Provision and Labour Market Needs In the Western Balkans Synthesis Report, European Commission 2016, Luxembourg: Publications Office of the European Union, 1-473.

2. Andrei S.C. (2015). Studiu de oportunitate inserţie pe piața muncii,http://www.carieracuimpact.ro/wpcontent/uploads /2015/04/I.-Studiu-oportunitate-de-insertie-pe-piatamuncii1.pdf accesed at 28.09.2017

3. Spatarelu E. (2015). Youth insertion on Labor Market, Procedia Economics and Finance, (32), 1020 - 1026.

4. Bălan M. (2014). Youth Labour Market Evolutions at Level in Romania, Internal Auditing \& Risk Management, 2 (34), 2937.

5. Vasile V., Vasile L. (2011). Youths on labour market. Features. Particularities. Pro-mobility factors forgraduates. Elements of balanced policy for labour migration, Romanian Journal of Economics 32, 1(41),97-123.

6. Diaconu L. (2014). Education and labour market outcomes in Romania, Eastern Journal of European Studies, 5 (1), 99114. 
7. Aceleanu M.I. (2011). The relationship between education and quality of life. Implications of the labour market in Romania, Journal of International Scientific Publications: Educational Alternatives, 9 (2), 171-182.

8. Vasile V., Vasile I. (2015). The educational level as a risk factor for youth exclusion from the labour market, Procedia Economics and Finance, 22, $64-71$.

9. Eurofound (2012). NEETs - Young people not in employment, education or training: Characteristics, costs and policy responses in Europe, Publications Office of the European Union, Luxembourg, 1-171.

10. ILO (2012). Global employment trends for youth 2012, International Labour Organization, Geneva, 1-98.

11. ILO (2013). Global Employment Trends for Youth 2013: A generation at risk. Geneva, 37-58.

12. Keep E. (2012). Youth Transitions, the Labour Market and Entry into Employment: Some Reflections and Questions, SKOPE Research Paper 108.

13. Vasile V. (2012). Crisis Impact on Employment and Mobility Model of the Romanian University Graduates, Procedia Economics and Finance, 3, 315-324.

14. Eurostat (2017). Eurostat sport statistics 2016 edition http://ec.europa.eu/eurostat, accessed at 06.01.2018.

15. Statista, The number of graduates in sport disciplines in the European Union for academic year of 2013, by country, https://www.statista.com/statistics/647669/eu-numberof-graduates-in-sport-disciplines-by-country, accessed at 06.01 .2018$.

16. Eurostat (2017). Statistics Explained, Employment in sport and average annual growth rate, 2011-15 T1.png, http://ec.europa.eu/eurostat/statistics-

explained/index.php/Employment_in_sport\#Employment_i n sport by sex.2C age and educational attainment, accessed at 07.01.2018.

17. Eurostat (2017). Share of women and men employed in sport, 2015.png, http://ec.europa.eu/eurostat/statisticsexplained/index.php/File:Share of women and men empl oyed in sport, 2015.png, at 07.01.2018.

18. Votik J. (2009). The analysis of chosen characteristics of Alumni who studied the physical education and sport at University of West Bohemia in Pilsen, Human Movement, 10(1), 67-74 